Młodzianowskiego - K. Przyboś. Antymakiawelizm jezuicki omawia S. Obirek SJ.

Ponadto XIX-wiecznym dziejom edukacji poświęcone sq̨ studia J. Dybca o roli studiów zagranicznych w kształtowaniu inteligencji gali- cyjskiej i L. Grzebienia SJ poświęcone konwiktowi szlacheckiemu we Lwowie w latach 1842 - 1848.

(D.Z.-S.)

\title{
W kręgu akademickiego Zamościa. Materialy z międzynarodowej konferencji, red. H. Gmiterek, Lublin 1996, ss. 344
}

Omawiana praca jest rezultatem konferencji nt. „Akademia Zamojska na tle praktyki edukacyjnej w Europie Srodkowo-Wschodniej (koniec XVI-koniec XVIII wieku)", która odbyła się w dniach 11 - 13 maja 1995 roku w Lublinie i Zamościu.

Tom rozpoczynaja rozprawy dotyczące obcych środowisk szkolnych - Akademia Strasburska i jej rektor Jan Sturm (Andre Seguenny), praskie środowisko akademickie (Jaroslav Panek), szkolnictwo na Morawach, ze szczególnym uwzględnieniem kolegium jezuickiego w Ołomuńcu (Jindrich Schulz i Jana Buresova).

Sylwetce fundatora poświęcili swe studia Stanisław Grzybowski (o Zamoyskim jako wychowawcy młodzieży szlacheckiej) oraz Marek Kuryłowicz (prawo rzymskie w studiach i koncepcjach akademickich Zamoyskiego). Rolę jego wnuka Jana Sobiepana Zamoyskiego i jego stosunek do Akademii omawia Eugeniusz Janas.

Profesorów Akademii Zamoyskiej dotyczą następujące rozprawy: Mariana Chachaja (o wykształceniu profesorów Akademii Zamojskiej), Mariana Lecha Klementowskiego (o ich udziale w sądownictwie Zamościa), promocje doktorskie w Akademii przedstawia Henryk Gmiterek; sylwetki profesorów omawiają: Halina Wiśniewska (Jana Ursinusa i Stanisława Niewieskiego), Bogdan Rok (Stanisława Duńczewskiego), Władysław Froch (Bazylego Rudomicza), Edward A. Mierzwa (Williama Bruce).
Funkcjonowaniu Akademii w środowisku miasta i Rzeczypospolitej poświęcony jest następny blok studiów. Roman Szust omawia kontakty lwowian z Akademią w XVII i XVIII wieku, Marian Pawlak kontakty szkolne północnych ziem Rzeczypospolitej z Zamościem, Witold Kłaczewski i Waclaw Urban szlachtę lubelską, jej stosunki z Akademią $i$ udział $w$ kształtowaniu elit intelektualnych Lubelszczyzny, kontakty Rusi Czerwonej z Zamościem omawia Wiesław Bondyra.

Agnieszka Sidorowska przedstawiła okoliczności likwidacji Akademii Zamojskiej w 1784 roku, a Bogdan Szyszka omówil szkoły będące kontynuatorkami tradycji Akademii.

Tom kończy studium Zdzisława Pietrzyka dotyczące źródeł do dziejów peregrynacji studenckich w XVI i XVII wieku na przykładzie Strasburga.

Tom ten, jak ma nadzieję jego redaktor Henryk Gmiterek, ma stać się ,istotnym przyczynkiem do opracowania nowej, krytycznej monografii Akademii Zamojskiej, lokującej ja w całokształcie ówczesnych uwarunkowań kulturowych, spolecznych, ekonomicznych i politycznych" ${ }^{1}$.

(D.Z.-S.)

1 H. Gmiterek, Przedmowa. w: Wkregu akademickiego Zamoscia. Materiały z międzynarodowej konferencji, red. H. Gmiterek, Lublin 1996, s. 6. 